National Bureau of Standards, U.S. Department of Commerce. These divisions are part of the Central Radio Propagation Laboratory.

Dr. E. K. Smith

DR. Smeth succeods C. Gordon Little, who was recently appointed chiof of the Contral Radio I'ropagation Laboratory. Since joining the Bureau's staff in 1951, Dr. Smith has investigated such ionospheric phenomena as sporadic$E, F$-region anomalies and studies of the atmospheric refractive index for non-ionized gases.

Mr. R. W. Knecht

Mr. Knecht succeeds Dr. Smith as chief of tho Ionosphere Research and Propagation Division. He joined the National Bureau of Standards in June 1949 immediately on graduation in physies from Union College in Schenectady, New York. After an initial assignment in Washington, he was transferred to Alaska, spending eight months at Barrow Radio Propagation Field Station and, aftorwards, two years at Anchorage as physicist-in-charge of the North Pacific Radio Warning Service. Since his return from Alaska in $1954, \mathrm{Mr}$. Knecht has worked primarily in the fields of ionospheric physies and solarterrestrial relationships. He was formerly chief of the Sun-Earth Relationships Soction. After exploring the possibilities of a satellite-borne top-side sounding experiment for investigating the ionosphere, Knecht promoted the development of Topsi, the U.S. fixed-frequency top-side sounding satellito scheduled for launching in the first half of 1963

\section{Scientific and Technical Personnel in the Federal Government}

Accondrng to Scientific and Technical Personnel in the Federal Government, 1959 and 1960, the professional scientific and technical staff in the Federal Government ineroased by 26 per cent to 156,000 between 1954 and 1960 (NSF 62-26. Pp. vi +79 . Washington, D.C.: Government Printing Office, 1962). The Department of Defence employed 37 per cent of these, 56,100 in 1959 and 57,400 in 1960 , more than two-thirds being engineers. The Veterans Administration employed about 29,000 in 1960, mostly in health occupations. The total included about 27,500 women in 1959 , mostly in health professions where about 58 per cent were women, compared with 3,900 or almost 8 per cent in scienco and less than 1 per cent in engineoring. The number ongaged in rosearch and development was relatively stable during 1958-60, and in 1960 about 44,000 were in resoarch and dovelopmont, about half in the Department of Defence. Of the 53,000 scientifie personnol in $1960,18,000$ wore in the physical sciences and noarly 22,000 in biological scionces. Non-professional scientific and technical staff in the Government increased by 11 per cent over the period 1958-60 from 75,200 to almost 83,500 , more than 35,800 in 1960 being in ongineering and 11,500 in mechanics. Almost 36,000 , or 43 per cent of the total, were in the Department of Defence and only 14,200, or 17 per cent, in research and devolopment.

\section{Problems in the Communication of Scientific and Technical Information}

IN September 1962 the Department of English and Liberal Studies of the Welsh College of Advanced Tech. nology began an investigation into the problems involved in the communication of scientific and technical information. A circular letter was sent to a group of fifty-four research contres and companies, inquiring what forms of writing they required and what difficulties and weaknosses, if any, they encounterod. All the thirty-one companies which replied expressed their concern with the present standards in technical writing, and nineteen suggested a visit to discuss the subject, while seven submitted detailed opinions or documentary evidence. All the companies welcomed the Department's positive measures to train undergraduates in written and spoken communication and were willing to co-operate in the investigation. Some were interested in suggestions for short courses for their graduate personnol, either in the college or in the companies themselves. A circular letter inquiring about the prevalence of communication problems in science and engineering departments in universities and colleges of advanced technology is being sent out to all such colleges and to selectod universities, and the writing of reports has been discussed with the professors of chemical, civil and electrical engineering in the University. of Nottingham, where much interest in standards of writing was shown. Staff in scientific departments at the Universities of Leeds, Liverpool and Reading has also boon approached, and it is proposed to make inquiries of a number of national research centres and institutes and of more companies. Exporiments havo already been made with testing methods in recent colloge courses and examinations, and consideration of the philosophical problems involved in the processes of written communication will commence shortly.

\section{Mental Health Book Review Index}

THE Mental Health Book Review Index contains a list of books relating in some way to mental health, and the title of each book is followed by references to reviews of the book which have appeared in the appropriate journals. Volume 7 deals in this way with some 300 now books and there are also included new reviews of books which have beon referred to in previous volumes (Pp. xiii +66 . Flushing, N.Y.: Miss Lois Affierback, Paul Klapper Library, Queens College, 1962. Annual subscription, 3 dollars). The field of mental health is widely interpreted and covers not only psychology and psychiatry and sociological aspects, but also a good many books of general cultural interest. For example, the present volume includes Sir Charies Snow's Rede Lecture on The Two Cultures and the Scientific Revolution, J. P. Sartre's Being and Nothingness and Teilhard de Chardin's The Phenomenon of Man. In these days when it is increasingly difficult for workers even to know what is published in their own field, not to mention in allied disciplines, this publication serves a very valuable purpose. The Index is sponsored, among others, by the World Federation for Mental Health.

\section{Animals}

THe aim of the new magazine, Animals, published by Knowledgo Publications, Ltd., at $2 s$. weekly, commencing January 8, is expressed by the editor-in-chief, Armand Denis: ". . . to interest you in every aspect of the animal world". The main appeal is visual, woll over half the space being given to pictures, four-fifths of which are superb colour photographs. Sir Julian Huxley and Sir Solly Zuckerman are patrons, and there soem to be links with the World Wildlife Fund, although what these may bo is not made precisely clear. The editorial board includes the Duke of Bedford, Gerald Durrell, Bernard Grzimek, Nicholas Guppy, Gavin Maxwell, Alan Moorehead, Peter Scott and Niko Tinbergen. The editor is John Chancellor, and the consulting editor Michael Tweedie. The text is less informative than should be expected for the price, an outstanding instance being an 800 -word article on the giant panda, which seems mainly concerned with how little we know of this species while failing to give as much as is known. (Porhaps somebody will one day explain why the giant panda was not named as one of the world's rarest animals until it was adopted as the symbol of the World Wildlife Fund (British Branch).) There is also a tendency for error and misstatement, not always trivial and sometimes needless, to creep in, and to maintain our interest in the animal world it may be necessary to bring the textual matter 